\title{
A Comparative Study of Stock Exchanges in China, Hong Kong, and Taiwan
}

\author{
William Cheng ${ }^{1} \&$ James $\mathrm{Wu}^{2}$ \\ ${ }^{1}$ Troy University, Montgomery, AL, USA \\ ${ }^{2}$ Aletheia University, Taipei, Taiwan \\ Correspondence: Dr. William Cheng, Troy University, Montgomery, AL, USA.
}

Received: November 9, 2017

Accepted: November 30, 2017

Online Published: December 10, 2017

doi:10.20849/iref.v1i1.245

URL: https://doi.org/10.20849/iref.v1i1.245

\begin{abstract}
Equity exchanges are sprouting in developing countries due to the privatization of state-owned enterprises. China officially opened its first recognized stock exchange, the Shanghai Security Exchange in December, 1990 and a few months later the Shenzhen Stock Exchange opened. This paper compares the micro-structure of the equity markets in China, Hong Kong, and Taiwan.

For a foreign investor, the markets in Hong Kong contain the least restriction and are the most accessible. Both China and Taiwan impose restrictions on foreign investment. China restricts foreign investment by only allowing the purchase of B shares Chinese exchanges, while Taiwan limits foreign investors to only four investment funds. China also allows for higher commissions on foreign investor purchases. In addition, Non-Chinese investors in A shares may be subject to a $20 \%$ withholding tax on that portion of dividend income that exceeds the People's Bank of China's one-year rate for the same period.

These discriminatory measures can be expected to have a negative impact on foreign capital inflows and to reduce the liquidity of these markets. The impact on the prices of shares and potential rates of return cannot be positive from these restrictions since, all else constant, lower demand implies lower price. It may be, however, that the inherent potential in these growing markets from recent political and economic changes may create high rates of return, despite the restrictions on capital flows. There are also other alternatives for capital inflows to direct stock investment, such as Foreign Direct Investment (FDI). FDI, in turn, may well flow through to higher stock prices.
\end{abstract}

Keywords: emerging markets, market regulations

\section{Introduction}

Equity exchanges are sprouting in developing countries due to the privatization of state-owned enterprises. China officially opened its first recognized stock exchange, the Shanghai Security Exchange in December, 1990 and a few months later the Shenzhen Stock Exchange opened. This paper compares the micro-structure of the equity markets in China, Hong Kong, and Taiwan. Data and analysis are obtained through Bloomberg's financial online service. Bloomberg provides 24-hour, instant and current financial, economic and political information covering markets around the globe. It also provides analytics, historical data, up-to-minute news reports, economic statistics and political commentaries. Constant upgrades and enhancements of the system are some of the most valuable attributes of the Bloomberg service.

\section{Profiles of Three Stock Markets}

Emerging markets share of total world market capitalization is $13 \%$. China and Taiwan's shares of total emerging market capitalization are $2.3 \%$ and $12.8 \%$, respectively. Hong Kong is listed under developed markets and its share in the total developed market capitalization is $1.8 \%$. Table 1 reports the market size, number of firms listed, turnover ratio, and P/E ratio of each market. The same statistics of the New York Stock Exchange (NYSE) in the U.S. are also reported for comparison.

Table 1 shows a combined listing of 1,471 firms for the three countries China, Hong Kong, and Taiwan, approximately half of the number listed on the New York Stock Exchange. The total market capitalization for these three countries is $\$ 638$ billion, less than one tenth of the size of the NYSE market cap. While both 
Taiwan's Stock Exchange and Hong Kong's Stock Exchange are of similar size, China's less than seven year old equity markets are much smaller. Even though much smaller in land mass and population, the Hong Kong Stock Exchange has more listed firms than China or Taiwan. Both the China and Taiwan Stock Exchanges have markedly higher turnover ratios (the proportion of trading volume to market capitalization) than Hong Kong or the NYSE. Taiwan's low transaction cost and high savings rate have been cited as the cause for the Taiwan Stock Exchange's lead in trading volume among Asian equity markets, second only to the Tokyo Stock Exchange. The price earnings $(\mathrm{P} / \mathrm{E})$ ratio reflects a similar phenomenon, with the Taiwan Stock Exchange higher than those in the Hong Kong and China Exchanges.

Table 1. Basic statistics of equity markets in China, Hong Kong, and Taiwan

\begin{tabular}{lcccc}
\hline Country & $\begin{array}{c}\text { Total Market Capitalization } \\
\text { (US \# Billion) }\end{array}$ & $\begin{array}{c}\text { Number of } \\
\text { Firms Listed }\end{array}$ & $\begin{array}{c}\text { Turnover } \\
\text { Ratio (\%) }\end{array}$ & P/E ratio \\
\hline China & 70.79 & 511 & 235.2 & 15.5 \\
Hong Kong & 303.70 & 585 & 77.6 & 17.2 \\
Taiwan & 264.10 & 375 & 323.1 & 28.3 \\
U.S. (NYSE) & $7,300.00$ & 2,907 & 56.1 & 18.9 \\
\hline
\end{tabular}

Source: Bloomberg/International Finance Corporation 2016.

\section{Characteristics of Three Stock Markets}

Table 2 summarizes the profiles of each market. The Table shows the stock exchanges in each country, the hours of operation, the type of trading system employed, a list of stock market indices, settlement and transfer information, types of securities traded on the exchanges, tax implications for foreign investors, reporting requirements, and investment regulations.

The two stock exchanges in the Greater China, the Shanghai Securities Exchange and the Shenzhen Stock Exchange, have relatively short trading hours (9:30 A.M. to 11:00 A.M. and 1:00 P.M. to 3:00 P.M.) as compared to the New York Stock Exchange's 62 hour trading day. The Taiwan Stock Exchange also has limited trading hours (9:00 A.M. to 12:00 Noon, Monday through Friday, and 9:00 A.M. to 11:00 A.M. on Saturday) in comparison to the NYSE. China has developed a security Trading Automated Quotation System which has equivalent trading hours to the NYSE.

Various types of securities are traded in all exchanges which include common and preferred shares, government and corporate bonds, convertibles, rights and warrants. However, in China, common shares are divided into A shares and B shares. A shares which include state, enterprise and individual shares can be traded by domestic investors. Foreign investors can only trade in B shares. B shares are traded in U.S. dollars on the Shanghai Securities Exchange and in Hong Kong dollars on the Shenzhen Stock Exchange.

Commissions are lowest in Taiwan. For shares traded on the Taiwan Stock Exchange, brokers charge $0.1425 \%$ of the amount traded. In Hong Kong, brokers collect a minimum of $0.25 \%$ on the sale of shares. The commissions are collected by brokers at Shanghai Stock Exchange is $0.5 \%$ of transacted value. On the Shenzhen Stock Exchange, the brokerage commission is $0.4 \%$ for A shares and $0.6 \%$ for B shares.

\section{Conclusion}

For a foreign investor, the markets in Hong Kong contain the least restriction and are the most accessible. Both China and Taiwan impose restrictions on foreign investment. China restricts foreign investment by only allowing the purchase of B shares Chinese exchanges, while Taiwan limits foreign investors to only four investment funds. China also allows for higher commissions on foreign investor purchases. In addition, Non-Chinese investors in A shares may be subject to a $20 \%$ withholding tax on that portion of dividend income that exceeds the People's Bank of China's one-year rate for the same period.

In Taiwan, dividends are subject to a $20 \%$ withholding tax if the investment is approved under the Statute for Investment by Foreign Nation and $35 \%$ if it is not. At the time of repatriation of income or capital, non-Taiwanese investors need to register with or gain permission from the Taiwanese Central Bank, which may restrict the timing of exchange release.

These discriminatory measures can be expected to have a negative impact on foreign capital inflows and to 
reduce the liquidity of these markets. The impact on the prices of shares and potential rates of return cannot be positive from these restrictions since, all else constant, lower demand implies lower price. It may be, however, that the inherent potential in these growing markets from recent political and economic changes may create high rates of return, despite the restrictions on capital flows. There are also other alternatives for capital inflows to direct stock investment, such as Foreign Direct Investment (FDI). FDI, in turn, may well flow through to higher stock prices.

Table 2a. Stock exchanges and their characteristics in China, Hong Kong, and Taiwan

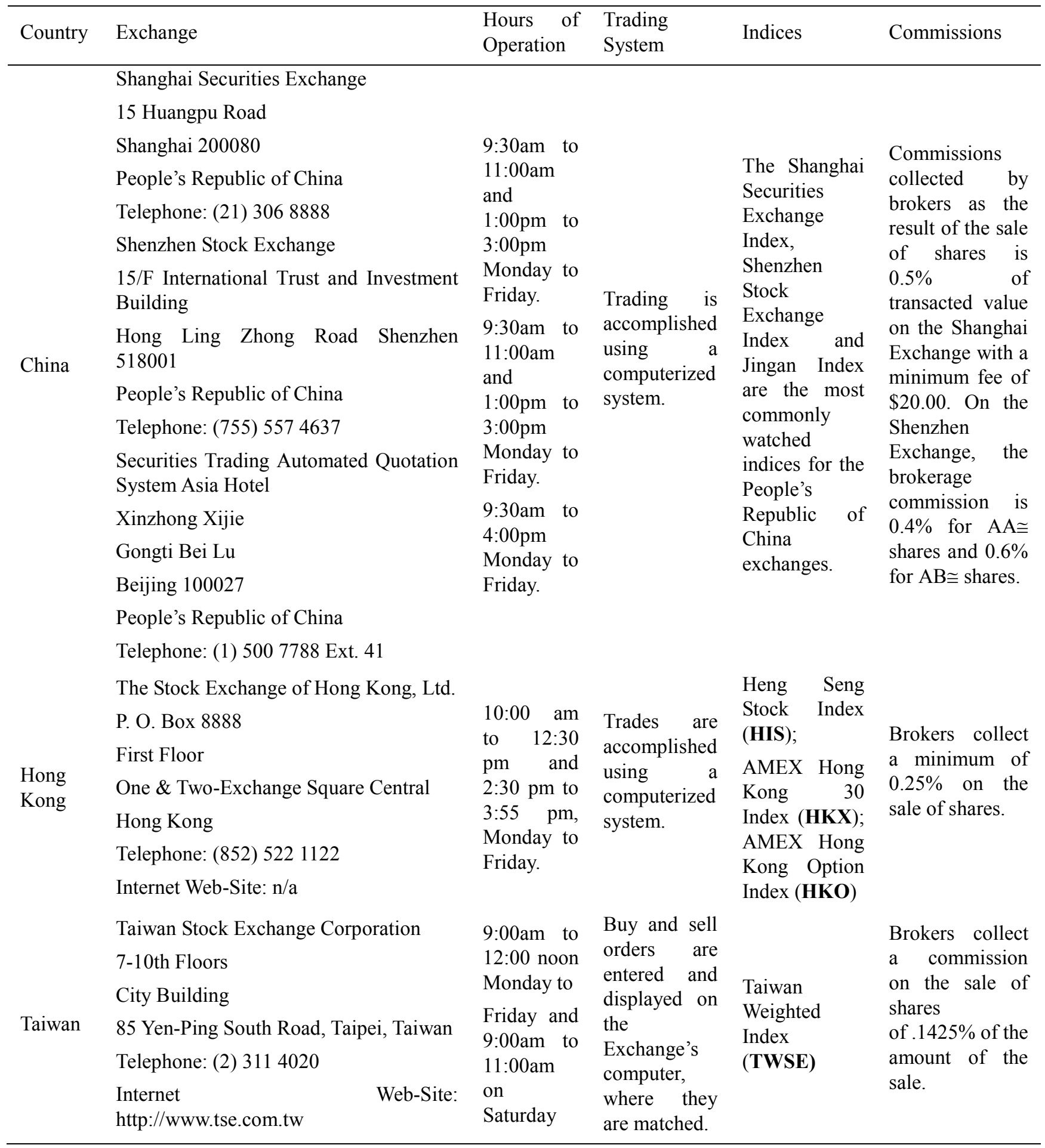

Source: Bloomberg/International Finance Corporation 2016. 
Table 2b. Stock exchanges and their characteristics in China, Hong Kong, and Taiwan

\begin{tabular}{|c|c|c|c|c|}
\hline Country & $\begin{array}{l}\text { Settlement } \\
\text { and Transfer }\end{array}$ & Types of Securities & $\begin{array}{l}\text { Tax Implications for Foreign } \\
\text { Investors }\end{array}$ & Reporting Requirements \\
\hline China & $\begin{array}{l}\text { Settlement } \\
\text { takes place } \\
\text { three trading } \\
\text { days } \\
\text { following } \\
\text { the } \\
\text { transaction } \\
\text { date. }\end{array}$ & $\begin{array}{lr}\text { Treasury } & \text { bonds, } \\
\text { financial instruments, } \\
\text { investment bonds, } \\
\text { corporate } & \text { bonds, } \\
\mathrm{AA \cong} \text { shares, which } & \text { comprise state, } \\
\text { enterprise and } \\
\text { individual shares, } \\
\text { and } \mathrm{AB} \cong \text { shares, } \\
\text { which are reserved } \\
\text { for non-Chinese } \\
\text { owners, are traded on } \\
\text { the Exchanges. }\end{array}$ & $\begin{array}{l}\text { Non-Chinese investors in } \\
\mathrm{AB} \cong \text { shares may be subject to } \\
\text { a } 20 \% \text { withholding tax on that } \\
\text { portion of dividend income } \\
\text { above the People's Bank of } \\
\text { China=s one-year Renminbi } \\
\mathrm{CD} \text { rate for the same period. }\end{array}$ & $\begin{array}{l}\text { Listed companies are required } \\
\text { to report any price sensitive } \\
\text { events to regulatory } \\
\text { authorities who then decide } \\
\text { whether the news should be } \\
\text { disclosed to the public. }\end{array}$ \\
\hline $\begin{array}{l}\text { Hong } \\
\text { Kong }\end{array}$ & $\begin{array}{l}\text { Share } \\
\text { certificates } \\
\text { and payment } \\
\text { are } \\
\text { exchanged } \\
\text { two days } \\
\text { following } \\
\text { the } \\
\text { transaction } \\
\text { date. }\end{array}$ & $\begin{array}{l}\text { Common, preference, } \\
\text { preferred common } \\
\text { and convertible } \\
\text { stocks, bonds, unit } \\
\text { trusts, rights and } \\
\text { warrants are traded } \\
\text { on the exchange. }\end{array}$ & $\begin{array}{l}\text { Neither dividends nor capital } \\
\text { gains are taxed that result } \\
\text { from shares owned in Hong } \\
\text { Kong companies. }\end{array}$ & $\begin{array}{l}\text { Listed companies are required } \\
\text { to disclose to their } \\
\text { shareholders and the } \\
\text { Exchange dividend } \\
\text { information, announcements } \\
\text { concerning profits and losses } \\
\text { and anything that may affect } \\
\text { their financial position. } \\
\text { Directors=reports must } \\
\text { disclose information on the } \\
\text { company=s and each } \\
\text { director=s bank loans and } \\
\text { other borrowings and each } \\
\text { director=s beneficial interest } \\
\text { in the share capital of the } \\
\text { company. }\end{array}$ \\
\hline Taiwan & $\begin{array}{l}\text { Settlement } \\
\text { takes place } \\
\text { the next } \\
\text { trading day } \\
\text { following } \\
\text { the } \\
\text { transaction. }\end{array}$ & $\begin{array}{l}\text { Common and } \\
\text { preference shares and } \\
\text { government, } \\
\text { corporate and } \\
\text { convertible bonds are } \\
\text { traded on the } \\
\text { Exchange. }\end{array}$ & $\begin{array}{l}\text { Non-Taiwanese investors are } \\
\text { permitted to invest in only } \\
\text { four investment funds. } \\
\text { Dividends paid to } \\
\text { non-Taiwanese investors are } \\
\text { subject to a } 20 \% \text { withholding } \\
\text { tax if the investment is } \\
\text { approved under the Statute for } \\
\text { Investment by Foreign } \\
\text { Nationals and } 35 \% \text { if it isn't. } \\
\text { Capital gains are not taxed. }\end{array}$ & $\begin{array}{l}\text { Listed companies are required } \\
\text { to report to the Securities and } \\
\text { Exchange Commission within } \\
\text { two days anything that may } \\
\text { affect the business or affairs } \\
\text { of the company. Companies } \\
\text { must submit annual, } \\
\text { semi-annual and quarterly } \\
\text { financial statements and } \\
\text { monthly operating reports. }\end{array}$ \\
\hline
\end{tabular}

Source: Bloomberg/International Finance Corporation 2016.

Table 2c. Stock exchanges and their characteristics in China, Hong Kong, and Taiwan

Country

Taiwan
Foreign Shareholder Limits

1. Overseas investor can purchase a total of 25 percent of a company $=\mathrm{s}$ shares.

2. Single foreign investor may buy up to 10 percent of an individual company $=\mathrm{s}$ shares.

Source: Bloomberg/International Finance Corporation 2016. 


\section{References}

Bloomberg Financials. (2016).

Booth, James R., \& Lena Chua. (1994, December 9). The Development of Stock Markets in China. FRBSF Weekly Letter, No. 94-42.

Chen, Haiyang, Michael Y. Klu, \& Joseph C. P. Shieh. (1991, Winter). The Wealth Effect of International Joint Ventures "The Case of US Investment in China". Financial Management, 31-41. https://doi.org/10.2307/3665710

China 15 Years of Reform. (1993, October). Beijing Review. 25-31.

Cracking the China Market. (1993, December 10). The Wall Street Journal Reports.

Exchanges Sprout in Developing Nations. (1995, November 14). The Wall Street Journal.

Rhee, S. Ghon, \& Rosita P. Chang. (1992). The Microstructure of Asian Equity Markets. Journal of Financial Service Research, 437-454. https://doi.org/10.1007/978-94-011-2180-4_8

\section{Copyrights}

Copyright for this article is retained by the author(s), with first publication rights granted to the journal.

This is an open-access article distributed under the terms and conditions of the Creative Commons Attribution license (http://creativecommons.org/licenses/by/4.0/). 